Research Article

\title{
Experimental Study on the Fine-Grained Uranium Tailings Reinforced by MICP
}

\author{
Rong Gui $\mathbb{D}^{1,2}$ Yu-xiang Pan $\mathbb{D}^{1,2}$ De-xin Ding, ${ }^{1,2}$ Yong Liu, ${ }^{2}$ and Zhi-jun Zhang $\mathbb{D}^{2}$ \\ ${ }^{1}$ Key Discipline Laboratory for National Defense for Biotechnology in Uranium Mining and Hydrometallurgy, \\ University of South China, Hengyang, Hunan 421001, China \\ ${ }^{2}$ Nuclear Resource Engineering College, University of South China, Hengyang, Hunan 421001, China \\ Correspondence should be addressed to Zhi-jun Zhang; zzj181@163.com
}

Received 15 June 2018; Accepted 5 September 2018; Published 17 October 2018

Guest Editor: Xinbao Yu

Copyright (C) 2018 Rong Gui et al. This is an open access article distributed under the Creative Commons Attribution License, which permits unrestricted use, distribution, and reproduction in any medium, provided the original work is properly cited.

Sporosarcina Pasteurii was chosen for the experiment to study the effect and mechanism of fine-grained uranium tailings reinforced by MICP. The biochemical characteristics of strains and microbial immobilization in uranium tailings were analyzed. The results showed that the $\mathrm{CaCO}_{3}$ production rate is positively correlated with the physiological activity of Sporosarcina Pasteurii and the concentration of calcium sources, and the higher the solution concentration of $\mathrm{CaCl}_{2}$, the lower the discharge rate of bacterial liquid from the sand column, but high concentration of $\mathrm{CaCl}_{2}$ solution will affect the uniform distribution and migration of bacteria in the uranium tailings. After 16 days, the direct shear was used to test the reinforcement effects of fine-grained uranium tailings by MICP. The cohesive force and the internal friction angle of fine-grained uranium tailings were increased by $140.1 \%$ and $46.7 \%$. The production amount of $\mathrm{CaCO}_{3}$ is $138.89 \mathrm{~kg} / \mathrm{m}^{3}$. The results showed that the MICP-reinforced technology can effectively improve the shear strength of the uranium tailings, and the experiment provides a new method for the reinforcement of the fine-grained uranium tailings dam.

\section{Introduction}

With the rapid development of nuclear industry in China, the demand for nuclear fuel increased rapidly. However, a large amount of radioactive waste was produced during the mining and metallurgy process of uranium, and many tailings reservoirs have been built to store them. As a special hydraulic structure, the safety of tailings reservoir has always been the focus of social attention. However, there were numerous serious accidents caused by failure of tailings dam at home and abroad for various reasons $[1,2]$. On September 8, 2008, a catastrophic failure accident occurred in the tailings reservoir of Xinta Mining Ltd. Co. Xiangfen County, Shanxi Province, China, that killed 281 people and claim a direct economic loss of 96.91 million yuan. On July 19, 1985, a fluorite tailings dam of Prealpi Mineraia failed at Stava, Trento, Italy. $200,000 \mathrm{~m}^{3}$ of tailings flowed $4.2 \mathrm{~km}$ downstream at a speed of up to $90 \mathrm{~km} / \mathrm{h}$ that killed 268 people and destroyed 62 buildings. However, due to the uranium tailings contain radionuclide such as uranium and radium, the catastrophe caused by failure of uranium tailings dam could be even more serious than other tailings dam, which also will cause severe radioactive pollution to the surrounding water and soil. Therefore, in order to ensure the stability of the uranium tailings dam, it is necessary to study the reinforcement technology of uranium tailings.

Traditional soil reinforcement techniques use sodium silicate, cement, and other chemical pulp as grouting materials which have some obstacles such as high cost, highenergy consumption, and permanent soil pollution [3-5]. Whiffin was first proposed to apply microbial diagenesis to cement the loose sand particles and achieved good effect in 2004 [6]. This has led to a research boom in the reinforcement of rock and soil by MICP technology. Paassen et al. applied the MICP technology to reinforce $100 \mathrm{~m}^{3}$ in situ sand base, and the unconfined compressive strength and stiffness of the treated sand base have a significant improvement [7]. Paassen applied the MICP technology to 
reinforce the 3-20 m gravel layer under the surface in the Netherlands, and no collapse happened in the reinforced gravel layer in the horizontal directional drilling and the gas pipeline laying [8]. Burbank et al. use the indigenous diagenetic microorganisms to reinforce the soil in the laboratory. The results show that calcium carbonate production in the soil was $20-48 \mathrm{~kg} / \mathrm{m}^{3}$, and the static penetration value of the reinforced soil increased by 2.2 times [9]. Soon et al. [10] applied the MICP technology to reinforce the lowpermeability soils and proved that the technology can also improve the mechanical properties of clay or silt. Canakci et al. applied the MICP technology to treat the peat soils with the low-strength and high-compression. After treatment, the shear strength and erosion resistance of reinforced peat soils increased, and calcium carbonate production in peat soil is $16 \%$ of the weight of the soil [11]. Mahawish et al. studied the feasibility of applying MICP technology to improve the mechanical properties of coarse sand and applying MICP technology to reinforce the gravel piles, sand piles, and bauxite columns. The uniaxial compressive strength of reinforced piles was up to $8.9 \mathrm{MPa}-2.3 \mathrm{GPa}$ [12]. Pusadkar et al. reinforced the sand slop in the laboratory by injecting bacteria (S. Pasteurii) and cement solution in sand, and the bearing capacity of slope footing increased significantly after MICP treatment [13]. Grabiec et al. applied the MICP technology to reinforce the incompletely compacted silty clays, and found that MICP technology can make diagenesis in the silty clays and significantly improve the soil stiffness [14].

The biological reinforcement technology aim at improving soil mechanical properties, and erosion resistance precipitate calcium carbonate crystals by the microbial biochemical activities. This technology is often referred to as microbial-induced calcite precipitation (MICP) [15]. At present, MICP technology has been successfully applied to solve geotechnical engineering problems, such as strengthening the bearing capacity of foundation soil, reducing the liquefaction of soils caused by earthquakes, reducing the swelling potential of foundations and roads, and reducing the permeability of tunnel walls and soils $[7,16-20]$. These researches have shown that the MICP technology has the advantages over the traditional reinforcement technology which not only reduced the disturbance of chemical grouting reinforcement but also has the advantages of economy, the environmental protection, and large curing radius.

Because the uranium tailings contain radionuclides and have different particle gradations from other porous media, so it is necessary to verify the feasibility of using the MICP technology to reinforce the fine-grained uranium tailings. Therefore, it is necessary to verify the feasibility of using the MICP technology to reinforce the fine-grained uranium tailings.

\section{Materials and Methods}

2.1. Strains and Culture Medium. The Sporosarcina Pasteurii used in the experiment was from the China General Microbiological Culture Collection Center (No. ATCC 11859).
The components of culture medium are shown in Table 1. Firstly, the urea solution was filtered by a steel sterilizing filter with $0.45 \mu \mathrm{m}$ and $0.22 \mu \mathrm{m}$ microporous permeable membranes. The urea solution was prepared separately during the sterilization because the urea is easy to decompose under high temperature. Then, the rest of the components were sterilized by pressurized steam sterilization at $121^{\circ} \mathrm{C}$ for 20 minutes. After preparation, the two solutions were mixed in proportion to get the required solution.

2.2. Uranium Tailings Samples. The samples were from a uranium tailings reservoir in south China. The screening test showed that the gradation parameters $d_{10}$ of the samples is $0.067 \mathrm{~mm}, d_{30}$ is $0.117 \mathrm{~mm}, d_{60}$ is $0.208 \mathrm{~mm}$, the nonuniform coefficient $C_{\mathrm{u}}$ is 2.663 , the curvature coefficient $C_{\mathrm{c}}$ is 0.893 , the relative density $G_{S}$ is 2.67 , the density $\rho$ is $1.454 \mathrm{~g} / \mathrm{cm}^{3}$, and the void ratio $e$ is 0.752 .

2.3. Fixative Solution and Cement Solution. The bacterial liquid is easily discharged from uranium tailings because the Sporosarcina Pasteurii has a diameter size within $0.5-3.0 \mu \mathrm{m}$. In order to reduce the discharge rate (the ratio of the OD600 value of the discharged bacterial liquid to the OD600 value of the inoculated bacterial liquid) of bacterial liquid from the sand column, $\mathrm{CaCl}_{2}$ was chosen as the fixative solution. According to related references $[9,13]$, the higher the concentration of the fixative solution was, the lower the discharge rate of the bacterial liquid was. But under a certain concentration of $\mathrm{CaCl}_{2}$, the inoculated bacterial liquid will form the floccules, and its diameter sizes enlarged with the increasing concentration of $\mathrm{CaCl}_{2}$ and blocked the pores between the uranium tailings, resulting in nonuniform distribution of bacterial liquid and unstable transmission of cement solution in the sand column. It indicated that the fixation and uniform distribution of the bacterial liquid in the sand column cannot simultaneously reach their optimum value, especially to different sand samples. So it is necessary to conduct the experimental analysis according to actual needs.

Therefore, in order to study the effects of different concentrations of the fixative solution on the fixation and migration of Sporosarcina Pasteurii in uranium tailings, five different concentrations of $\mathrm{CaCl}_{2}$ solution $(0.005 \mathrm{~mol} / \mathrm{L}$, $0.015 \mathrm{~mol} / \mathrm{L}, \quad 0.025 \mathrm{~mol} / \mathrm{L}, \quad 0.035 \mathrm{~mol} / \mathrm{L}$, and $0.045 \mathrm{~mol} / \mathrm{L}$ ) were set to in the experiment. Based on the experimental results, the cement solution was determined with $0.5 \mathrm{~mol} / \mathrm{L}$ urea and $0.5 \mathrm{~mol} / \mathrm{L} \mathrm{CaCl}_{2}$ solution (equivalent volume mixture).

2.4. Physical Model. The physical model of the sand columns were constructed of polyvinyl chloride (PVC) $7 \mathrm{~cm}$ height with an inner diameter of $6.18 \mathrm{~cm}$ (the same as the diameter size of the sand samples in the direct shear test). The upper part of the experimental device have a grouting port connected to the sealed plastic bottle with a rubber hose and a reserved vent. The grouting pipe and the outlet pipe have 
TABLE 1: Composition of culture medium used in the experiment.

\begin{tabular}{lcc}
\hline Medium name & $\mathrm{pH}$ & Components \\
\hline CASO liquid medium & 7.3 & $\begin{array}{c}\text { Casein } 15 \mathrm{~g} \text {, soy peptone } 5 \mathrm{~g} \text {, sodium chloride } 5 \mathrm{~g}, \\
\text { urea } 20 \mathrm{~g} \text {, nickel chloride } 0.0013 \mathrm{~g} \text {, deionized water } \\
1000 \mathrm{~mL}\end{array}$ \\
\hline CASO solid medium & 7.3 & $\begin{array}{c}\text { Casein } 15 \mathrm{~g} \text {, soy peptone } 5 \mathrm{~g} \text {, sodium chloride } 5 \mathrm{~g}, \\
\text { urea } 20 \mathrm{~g} \text {, nickel chloride } 0.0013 \mathrm{~g}, 20 \mathrm{~g} \text { agar powder, } \\
\text { deionized water } 1000 \mathrm{~mL}\end{array}$ \\
\hline Mixed medium & 7.3 & $\begin{array}{c}\text { Casein } 15 \mathrm{~g} \text {, soy peptone } 5 \mathrm{~g} \text {, sodium chloride } 5 \mathrm{~g}, \\
\text { urea } 30 \mathrm{~g}(0.5 \mathrm{~mol} / \mathrm{L}), \text { nickel chloride } 0.0013 \mathrm{~g}, \\
\text { calcium chloride } 55.5 \mathrm{~g}(0.5 \mathrm{~mol} / \mathrm{L}), \text { deionized water } \\
1000 \mathrm{~mL}\end{array}$ \\
\hline
\end{tabular}

a rubber pipe with a water stop valve. In order to prevent the sand from entering the grouting pipe and outlet pipe, two gauze layers were set on both sides of the sand columns. And, two gravel layers (particle size $2 \pm 0.5 \mathrm{~mm}$ ) were laid on both sides of the sand column to avoid scouring the uranium tailings and clogging of the grouting mouth during the experiment. The experimental device is shown in Figure 1 and Figure 2.

\section{Test Procedure and Methods}

3.1. Activation and Propagation of Sporosarcina Pasteurii Strains. An inoculating loop was used to scrape the strains into a tube which contains $10 \mathrm{~mL}$ CASO liquid medium, and the tube was kept in a constant-temperature shaking incubator which was set at $30^{\circ} \mathrm{C}$ for 2 days. Then, an inoculating loop was used to take the culture supernatant and perform streak inoculation on a solid medium plate. Place the inoculated plate in a constant-temperature incubator which was set at $30^{\circ} \mathrm{C}$ for 2 days. After 2 days, the milky colonies formed on the solid medium (Figure 3). An inoculating loop was used to scrape the strains from the solid medium into a conical flask with $100 \mathrm{~mL}$ of CASO liquid medium. Place the conical flask in a constanttemperature shaking incubator which was set at $30^{\circ} \mathrm{C}$ for 2 days. The rotation speed was controlled at $130 \mathrm{r} / \mathrm{min}$. From Figure 4, obvious turbidness was observed in the inoculated conical flask compared with the blank reference after $48 \mathrm{~h}$.

\subsection{Biochemical Characteristics of the Strains under Cement Solution}

3.2.1. Experiment Method. $200 \mathrm{~mL}$ of cement solution was poured into three $250 \mathrm{ml}$ of conical flasks. The $\mathrm{OD}_{600}$ value of bacterial liquid was diluted to 1.0 with CASO liquid medium. Then, $2 \mathrm{~mL}$ of the diluted bacterial liquid inoculated in the conical flask (inoculation amount was 1\% $(\mathrm{v} / \mathrm{v}))$ which was placed in a constant-temperature shaking incubator which was set at $30^{\circ} \mathrm{C}$. The rotation speed was controlled at $130 \mathrm{r} / \mathrm{min}$. Then determine the number of bacteria in culture fluid, ammonia concentration, $\mathrm{pH}$ value, and $\mathrm{CaCO}_{3}$ production after being cultured for $2 \mathrm{~h}$, $4 \mathrm{~h}, 8 \mathrm{~h}, 12 \mathrm{~h}, 18 \mathrm{~h}, 24 \mathrm{~h}$, and $36 \mathrm{~h}$.

\subsubsection{Detection Method}

(1) Number of Bacteria. In this experiment, the protein nucleic acid analyzer was used to determine the $\mathrm{OD}_{600}$ value of the bacterial liquid and substitute the value into formula (1) [21] to calculate the total number of bacteria in the bacterial liquid.

$$
Y=8.59 \times 10^{4} Z^{1.3627}
$$

Where $Z$ is the value of $\mathrm{OD}_{600}$ and $Y$ is thethe concentration of bacterial liquid (units $/ \mu \mathrm{L}$ ).

However, this formula is valid for the $\mathrm{OD}_{600}$ value between 0.2 and 0.8. Bacterial liquid should be diluted and then converted if it exceeds this range.

(2) Ammonia Concentration. Take $40 \mathrm{~mL}$ of culture supernatant for different culture periods with a centrifuge tube and place them in a refrigerated centrifuge at a speed of $8000 \mathrm{r} / \mathrm{min}$ for 20 minutes. Pipette $10 \mathrm{~mL}$ of centrifuge supernatant into the colorimetric tube, and the ammonia concentration was determined by the spectrophotometric method.

(3) $\mathrm{pH}$ Value. The $\mathrm{pH}$ value of the culture solution was measured by precision bench-top $\mathrm{pH}$ meter.

(4) $\mathrm{CaCO}_{3}$ Production. The acid dissolution method was adopted to determine the calcium carbonate content in the mixed medium as follows: the culture liquid in the conical flask was filtered with filter paper after incubating in a constant-temperature shaking incubator for a period of time, and then put the filtered paper containing residues and the conical flask into a beaker at $70^{\circ} \mathrm{C}$ for 24 hours. The residues in the conical flask and the filter paper after drying are shown in Figure 5. The total mass of filter paper, beaker, and conical flask is $W_{1}$.

$100 \mathrm{~mL}$ dilute hydrochloric acid ( $2 \mathrm{~mol} / \mathrm{L})$ was slowly added to the conical flask and to the beaker containing the filter paper, and stirred with a glass rod until no gas generated. After drying, the process was repeated once more, and the total mass of filter paper, beaker, and conical flask is $W_{2}$. According to chemical reaction formula (2), the difference in mass between $W_{2}$ and $W_{1}$ before and after the reaction is the difference between $\mathrm{CaCO}_{3}$ and $\mathrm{CaCl}_{2}$. The content of $\mathrm{CaCO}_{3}$ can be calculated by the following formula: 


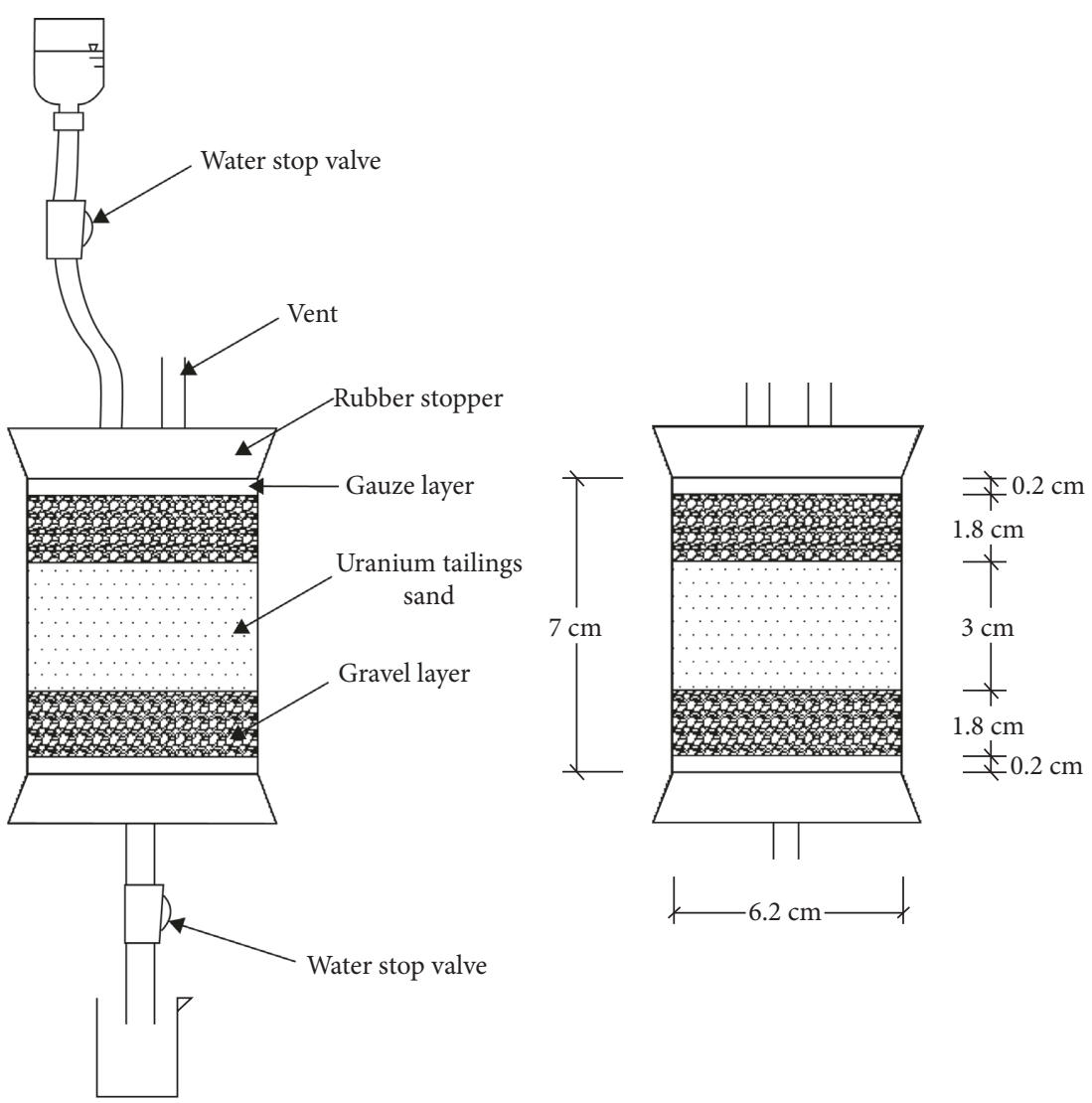

FIgURE 1: Schematic diagram of the MICP experimental device.

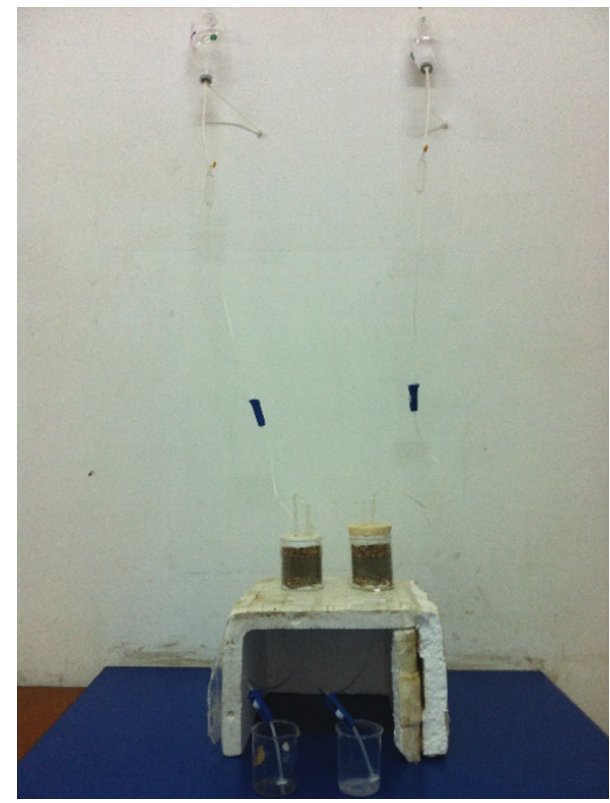

FIgure 2: Physical model of the MICP experimental device.

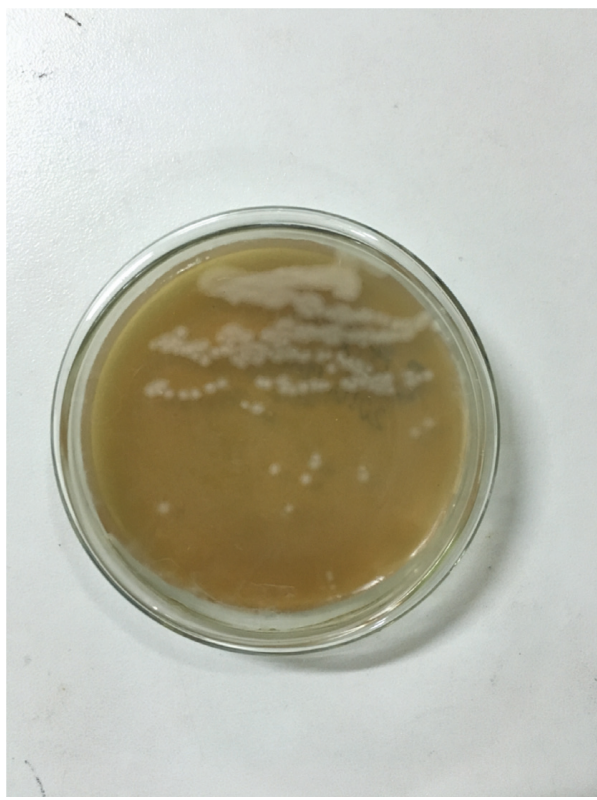

Figure 3: Sporosarcina Pasteurii strains on solid medium. 


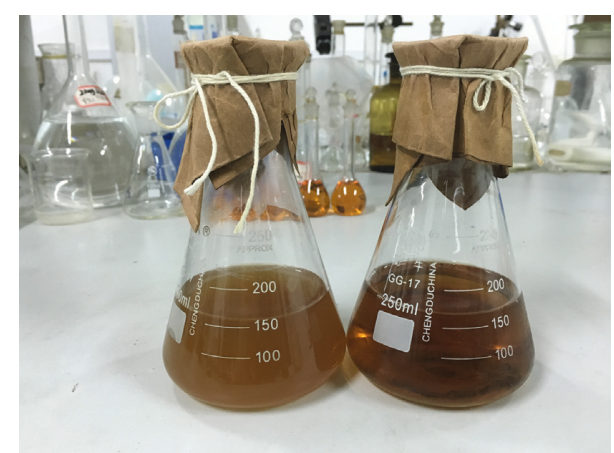

Figure 4: Sporosarcina Pasteurii strains were cultured in liquid medium for 2 days (left side is inoculated conical flask and the right side is blank reference).
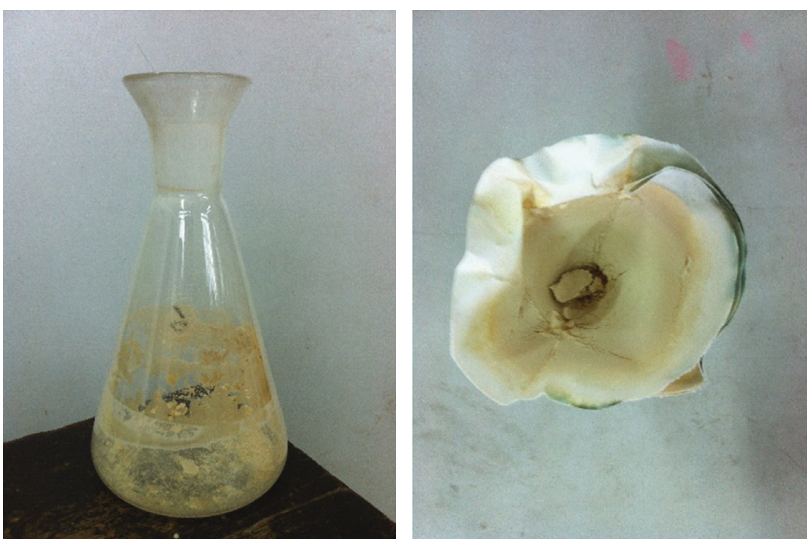

FIGURE 5: The residues in the conical flask and on the filter paper after drying.

$$
\begin{aligned}
& m_{\mathrm{CaCO}_{3}}=100 \times \frac{W_{2}-W_{1}}{(111-100)}, \\
& \underset{100}{\mathrm{CaCO}_{3}}+2 \mathrm{HCl} \longrightarrow \underset{111}{\mathrm{CaCl}_{2}}+\mathrm{H}_{2} \mathrm{O}+\mathrm{CO}_{2} \uparrow .
\end{aligned}
$$

3.3. Domestication of Sporosarcina Pasteurii in the Radioactive Effluent of Uranium Tailings. $2 \mathrm{ml}$ bacterial suspension was inoculated into the conical flask which contains $10 \mathrm{~mL}$ CASO liquid medium and $100 \mathrm{ml}$ sterilized radioactive effluent of uranium tailings. The flask was placed in the constant-temperature shaking incubator for $24 \mathrm{~h}$ which was set at $30^{\circ} \mathrm{C}$, and the rotation speed was controlled at $200 \mathrm{r} / \mathrm{min}$. The domesticated culture medium was taken by an inoculating loop and inoculated on a solid medium plate. Place the inoculated plate in a constanttemperature incubator which was set at $30^{\circ} \mathrm{C}$ for 2 days. After the strains grew up, they were added to the mixed medium again. The strains were domesticated once every 5 days for 8 successive generations. Test. Firstly, the deionized water was slowly injected into the sand column to discharge the gas and to saturate the sand samples. The flow rate of the deionized water was controlled to $2 \mathrm{~mL} / \mathrm{min}$ by adjusting the stop valve at the injection port. The $\mathrm{OD}_{600}$ value of the outflow liquid was detected and reached zero after $12 \mathrm{~h}$. The water content of the saturated sand column is $38.9 \mathrm{~mL}$ by calculating the pore volume. According to related references, the inoculated amount of bacterial liquid is 1.2 times of water content of the saturated sand $(50 \mathrm{~mL})$. Bacterial liquid and $\mathrm{CaCl}_{2}$ solution were mixed at a ratio of $1: 1$, and the flow rate of mixed liquid was adjusted to $1 \mathrm{~mL} / \mathrm{min}$. After $12 \mathrm{~h}$, the outlet water stop valve was opened, and $5 \mathrm{~mL}$ of effluent was collected to determine the $\mathrm{OD}_{600}$ value.

3.5. Fine-Grained Uranium Tailings Reinforcement Test. $25 \mathrm{~mL}$ bacterial liquid $\left(\mathrm{OD}_{600}=1.1\right)$ and $\mathrm{CaCl}_{2}$ solution were injected into the sand column with equal volume each day, and the injection flow rate was controlled at $1 \mathrm{~mL} / \mathrm{min}$. Eight sand column models inoculated with bacterial liquid were prepared for experiment, and another eight sand column models as a blank reference. Two molds were detached on the 4 th, 8th, 12th, and 16th days, respectively; the uranium tailings reinforced by MICP is shown in Figure 6.

After the sand column was vertically and smoothly placed into the geotechnical ring cutter, $0.5 \mathrm{~cm} \times$ $0.5 \mathrm{~cm} \times 0.5 \mathrm{~cm}$ sand samples were takeout with a soil spatula, and it was placed in a thermostatic oven dried for 24 hours at $105^{\circ} \mathrm{C}$. The microstructure of the reinforced sand samples was observed by scanning electron microscopy (SEM) to observe the precipitation structure of $\mathrm{CaCO}_{3}$ and to analyze reinforcement mechanism of MICP.

The geotechnical tests were conducted to determine the reinforcement effects of fine-grained uranium tailings by MICP, and the reinforced sand samples were loaded into the shear box to test the shear strength. The vertical normal stress is $50 \mathrm{kPa}$ and $100 \mathrm{kPa}$. The control shear rate is $0.8 \mathrm{~mm} / \mathrm{min}$. The direct shear test is shown in Figure 7.

The sand samples after the test were ground with a grinder and dried in a thermostatic oven for 24 hours. $50 \mathrm{~g}$ of sand samples after grinding and $100 \mathrm{~mL}$ hydrochloric acid ( $2 \mathrm{~mol} / \mathrm{L})$ was added slowly into a beaker and stirred with a glass rod until no gas generated. Then, place it in a thermostatic oven for 24 hours, and the process was repeated once more. After drying, the sand samples were weighed in $m^{\prime}$.

The mass difference between $m^{\prime}$ and 50 before and after the reaction were the mass difference between $\mathrm{CaCO}_{3}$ and $\mathrm{CaCl}_{2}$. According to the chemical equation, the mass of $\mathrm{CaCO}_{3}$ can be calculated by the following:.

$$
m_{\mathrm{CaCo}_{3}}=100 \times \frac{m^{\prime}-50}{(111-100)} .
$$

The calculated mass of $\mathrm{CaCO}_{3}$ subtracted with the original mass of $\mathrm{CaCO}_{3}$ was the mass of $\mathrm{CaCO}_{3}$ generated in each sand column. The volume of sand samples was 


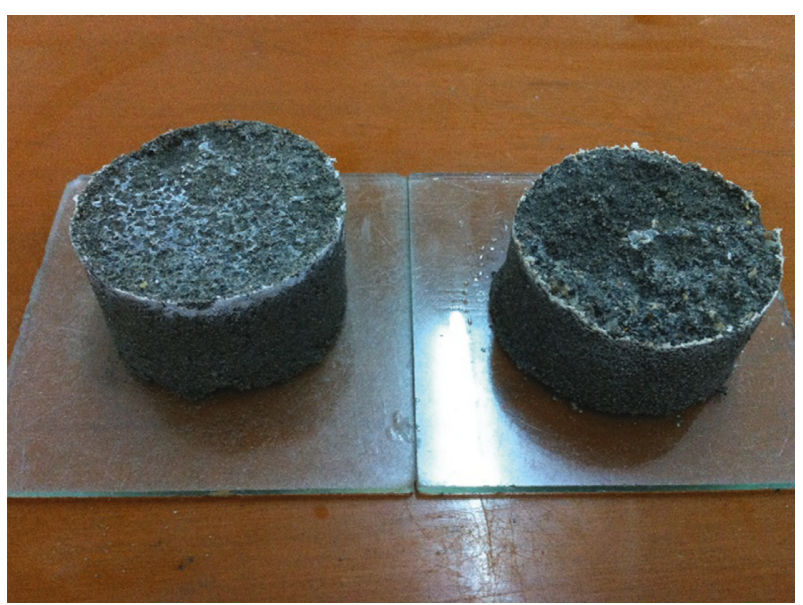

Figure 6: Uranium tailings reinforced by MICP.
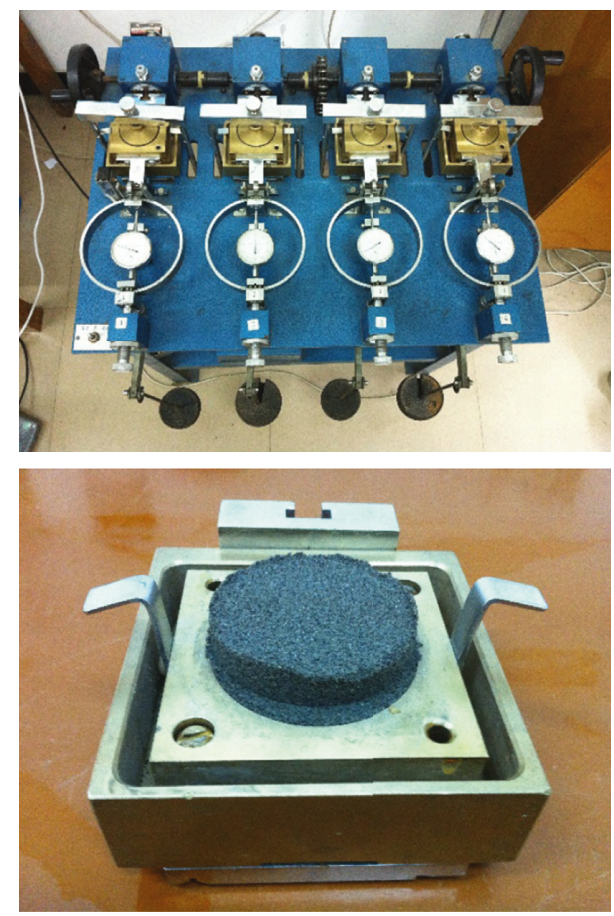

FIgURE 7: Direct shear test and shear failure of specimen.

calculated according to the density of each sand column, so the mass of $\mathrm{CaCO}_{3}$ produced per unit volume can be calculated.

\section{Test results}

\subsection{Physiological and Biochemical Characteristics of Strains in the Environment of Cement}

4.1.1. The Changes in Bacterial Number and $p H$ Value as Function of Time. The changes in bacterial number and $\mathrm{pH}$ value in mixed media as function of time was obtained by culturing Sporosarcina Pasteurii for $36 \mathrm{~h}$ in a shake flask, as shown in Figure 8 . The growth curve of bacterial number basically conforms to the Gompertz-Richards model and

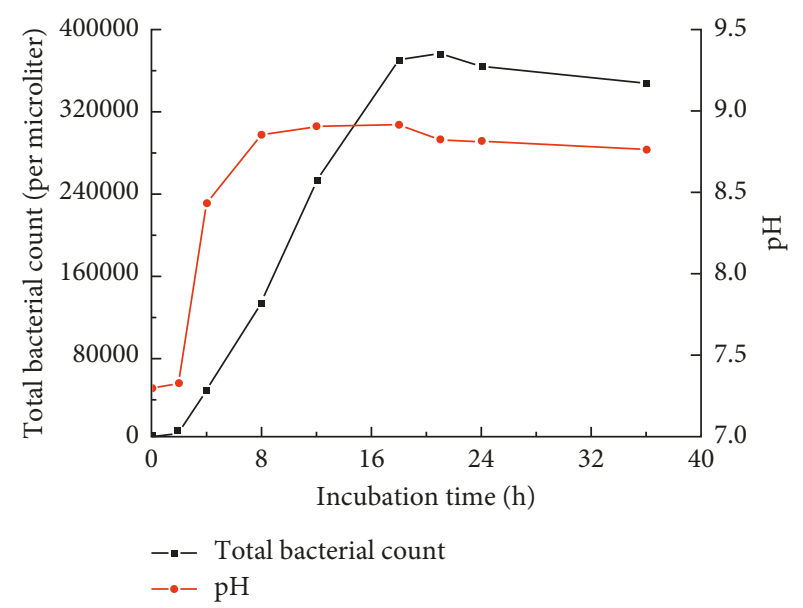

FIgURE 8: Changes in bacterial density and $\mathrm{pH}$ value in mixed media as function of time.

could be divided into three stages. The lag stage phase $(0-2 \mathrm{~h})$ is not very obvious for the Sporosarcina Pasteurii chosen for the experiment is excellent and has adapted to the test by cycle culturing. In this stage, the $\mathrm{pH}$ value of the solution did not change substantially. Almost no increase in the number of Sporosarcina Pasteurii was observed, but its anabolism was active to provide sufficient enzymes, energy, and intermediate metabolites for subsequent growth and reproduction of bacteria.

In the logarithmic phase $(2-18 \mathrm{~h})$, the number of bacteria has a steady geometric growth. The biological morphology was typical, and the biological activity was strong. A large number of urease was produced to decompose the urea into carbonate and ammonium ions, so the $\mathrm{pH}$ value of solution rises from 7.3 to about 9.0. Therefore, it is suitable for choosing the strains in this phase for the following inoculation experiment.

In the stationary phase (18-24 h), the number of bacteria reached a peak and tended to be stable, but high activity of the strains was maintained. Some adverse effects have been appeared such as the overconsumption of nutrients in the medium, the accumulation of toxic metabolites (such as alcohol and $\mathrm{H}_{2} \mathrm{O}_{2}$ ), the increase of $\mathrm{pH}$ causing changes in bacterial morphology and biological activity, decreased bacterial growth rate, and increased relative death of bacteria, but bacterial number attains equilibrium between proliferation and death, and the spores began to form in this phase.

In the decline phase (after $24 \mathrm{~h}$ ), the bacterial number tended to increase slowly and the number of dead bacteria increased significantly. The number of live bacteria was inversely related with the culture time, and the $\mathrm{pH}$ value of the solution was slightly declined, and the physiological metabolic activity tends to stagnant.

4.1.2. The Changes in Ammonia Nitrogen Concentration and $\mathrm{CaCO}_{3}$ Production as Function of Time. The changes in ammonia nitrogen concentration and $\mathrm{CaCO}_{3}$ production as function of time was obtained by shaking flask experiments 
in cement solution, as shown in Figure 9. After inoculating the Sporosarcina Pasteurii into the mixed culture medium for 4 hours, the concentration of ammonia nitrogen rose rapidly, which indicated that Sporosarcina Pasteurii had a high urease activity in the initial state, but the production rate of $\mathrm{CaCO}_{3}$ increase slowly because of the bacteria are still in the lag phase or logarithmic phase which have insufficient bacteria and urease. In the following 14 hours, the bacteria maintained a high level of physiological activity which resulted in a continuous increase of $\mathrm{CaCO}_{3}$ production. And, the ammonia nitrogen production began to decline because ammonia nitrogen volatilize to the outside during the shaking culture.

At $18 \mathrm{~h}$ after inoculation, production rate of the calcium carbonate slows down. On the one hand, the ratio of calcium ions converted into crystals in the solution reached $80 \%$, and calcium ion concentration has become the limiting factor to affect the process of microbial mineralization. On the other hand, the activity of the bacteria decreased because of limited nutrients and deteriorated external conditions in the culture medium. Especially, the amount of calcium carbonate remains stable as the bacteria entered the decline stage after $24 \mathrm{~h}$. The results showed the following: $\mathrm{CaCO}_{3}$ production of Sporosarcina Pasteurii in the cement solution was positively correlated with its physiological activity and calcium concentration.

\subsection{Test Results of Bacterial Liquid Fixation in Uranium} Tailings Sand. Different concentrations of $\mathrm{CaCl}_{2}$ solution and bacterial liquid were injected into the sand column $12 \mathrm{~h}$ later, the effluent was collected, its concentrations of $\mathrm{CaCl}_{2}$ and the $\mathrm{OD}_{600}$ value were determined, and the results are shown in Figure 10. We can see that the higher the concentration of $\mathrm{CaCl}_{2}$ solution is, the lower the $\mathrm{OD}_{600}$ value of the effluent is, and the value was followed by a logarithmic decrease. However, considering the low concentration of $\mathrm{CaCl}_{2}$ solution is conducive to the transmission of bacteria liquid, $0.025 \mathrm{~mol} / \mathrm{L} \mathrm{CaCl}_{2}$ solution was chosen as the fixative solution in the experiment, and the fixation rate of bacterial liquid was $92.14 \%$ by experiment (the fixation rate was higher than 90\%).

\subsection{Test of Uranium Tailings Reinforced by MICP}

4.3.1. Changes of Shear Strength of Reinforced Uranium Tailings. The direct shear was used to test the variation of shear properties of reinforced uranium tailings over time. The results are shown in Figure 11; we can see the internal friction angle, cohesive force, and shear strength of uranium tailings reinforced by MICP were significantly increased. And, the shear strength growth rate of grouting reinforcement from 8 to 12 days is the highest due to the calcium carbonate crystals binds sand particles together and reinforces the structure strength of the sand. After 16 days, the cohesion of reinforced uranium tailings increased from $9.59 \mathrm{kPa}$ to $23.03 \mathrm{kPa}$, the growth rate was $140.1 \%$, the internal friction angle of reinforced uranium tailings increased from $29.1^{\circ}$ to $42.7^{\circ}$, and the growth rate

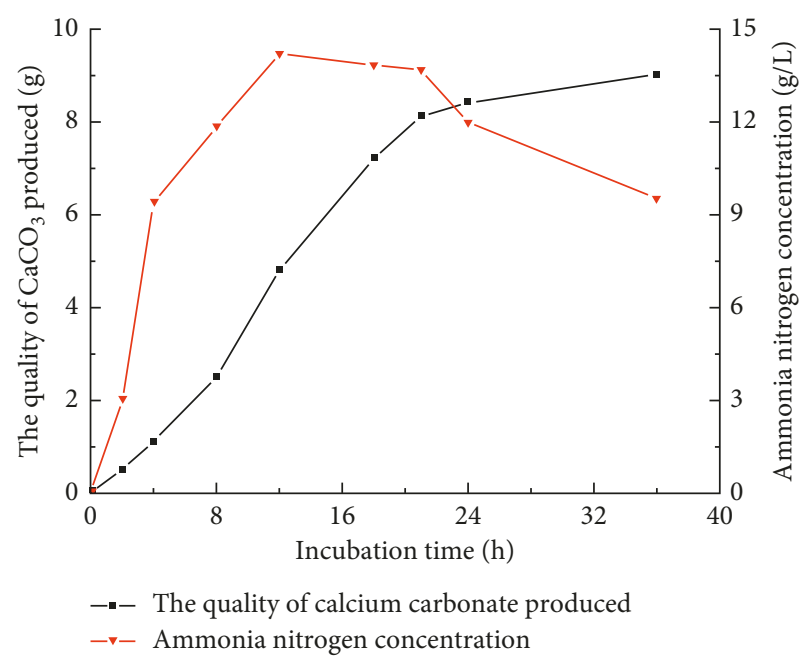

FIGURE 9: The changes in ammonia nitrogen concentration and $\mathrm{CaCO}_{3}$ production as function of time.

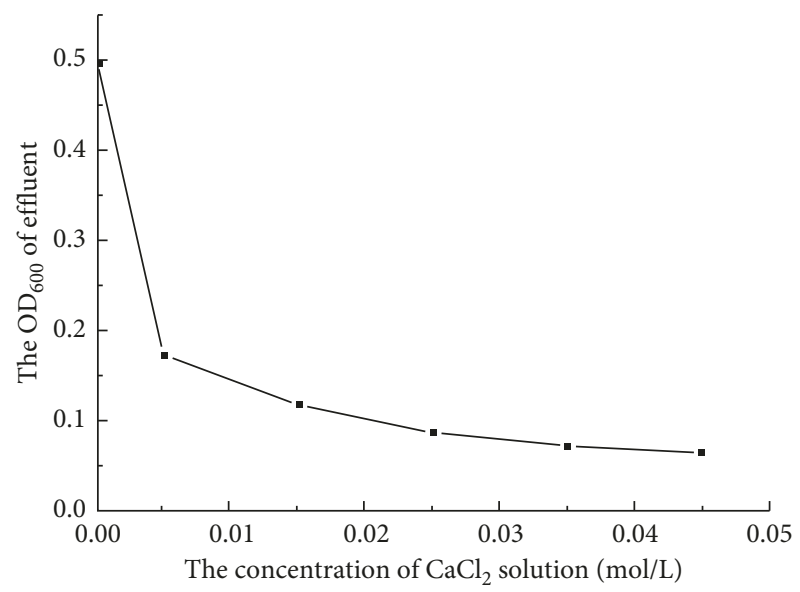

Figure 10: Curve of the $\mathrm{OD}_{600}$ value of effluent with the concentration of $\mathrm{CaCl}_{2}$ solution.

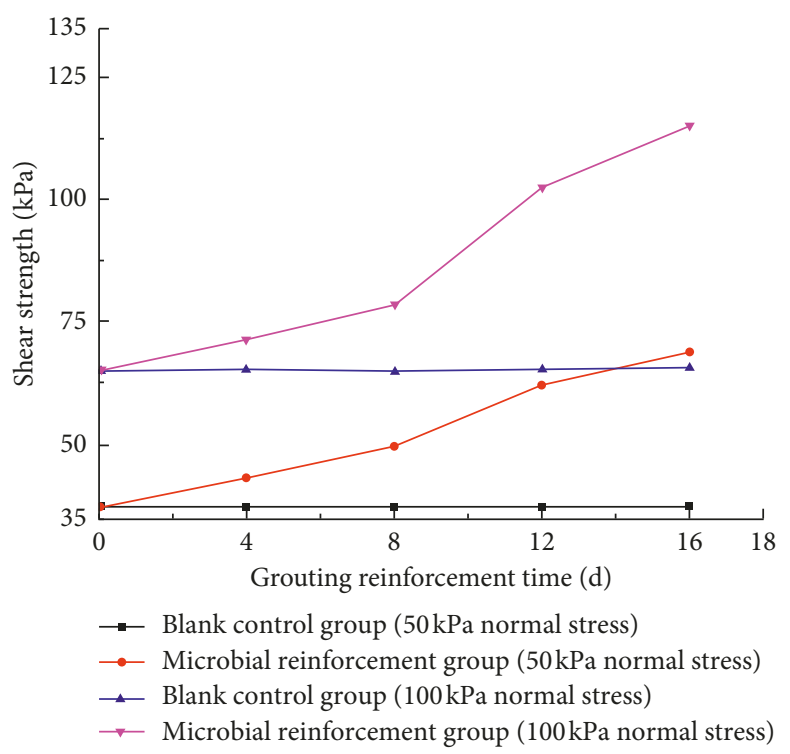

FIgURE 11: The changes in shear strength of uranium tailings reinforced by MICP as function of time. 


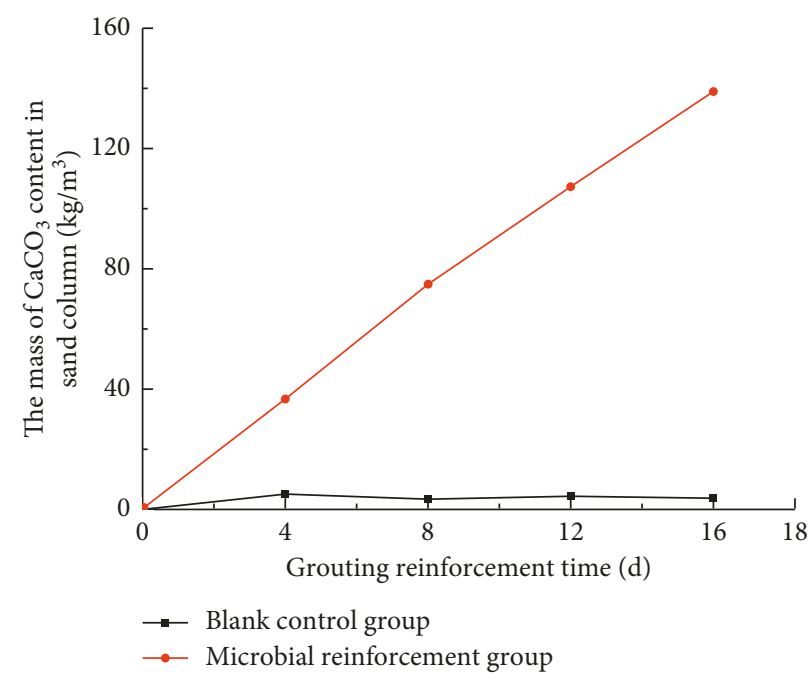

Figure 12: The changes in $\mathrm{CaCO}_{3}$ production of uranium tailings reinforced by MICP as function of time.

was $46.7 \%$. Under the normal stress of $50 \mathrm{kPa}$, the shear strength increased from $37.42 \mathrm{kPa}$ to $69.02 \mathrm{kPa}$, and the growth rate was $84.6 \%$. Under the normal stress of $100 \mathrm{kPa}$, the shear strength increased from $65.25 \mathrm{kPa}$ to $115.14 \mathrm{kPa}$, and the growth rate was $76.5 \%$. However, the shear strength of the blank reference group did not change substantially. The results showed that MICP technology can increase shear strength of uranium tailings effectively.

\subsubsection{The Change in $\mathrm{CaCO}_{3}$ Production in Uranium Tailings} as Function of Time. The change of $\mathrm{CaCO}_{3}$ production was determined by the acid dissolution method, the changes in $\mathrm{CaCO}_{3}$ production as a function of time are shown in Figure 12, and utilization rate of calcium ion of MICP was calculated after experiment; the results are shown in Table 2, about $65 \%$. We can see that the inoculated group has more $\mathrm{CaCO}_{3}$ production and higher calcium ion utilization rate than blank reference group. However, the utilization rate should be improved compared with the $90 \%$ utilization rate of shaking flask experiment in the cement liquid in 4.1.

To further research the differences in $\mathrm{CaCO}_{3}$ production of MICP between the uranium tailings environment and the cement liquid environment, detaching the molds and observing the cementation of different layers of sand column after grouting (Figure 13), a lot of $\mathrm{CaCO}_{3}$ crystal deposits were found in the buffer gravel layer in the grouting hole and in the gauze layer. Therefore, the reason for the low utilization rate of calcium ion in uranium tailings is that $\mathrm{CaCO}_{3}$ particles were deposited in the gravel layer and gauze layer, or the bacteria were washed away during the grouting process, resulting in insufficient nucleus to form the $\mathrm{CaCO}_{3}$.

\subsubsection{SEM Results and Analysis of Reinforcement} Mechanism. To research the reinforcement mechanism of uranium tailings reinforced by MICP, SEM images were observed for sand samples after the experiment. The scanning electron micrographs are presented in Figure 14; it can be observed that, between the uranium tailings, particles were filled with a large number of white calcite crystals which are irregular particles, and there are overlapping phenomena. These crystals bind uranium tailings together and form bio-sandstones, which reduces the porosity of sand samples, and greatly improve their shear strength.

\section{Conclusion}

In this paper, Sporosarcina Pasteurii was chosen for the experiment to study the effect and mechanism of finegrained uranium tailings reinforced by MICP. The experiments were performed in shaking cement solution and in sand column, and biochemical properties and mineralization efficiency were analyzed. The effect and mechanism of uranium tailings reinforced by MICP were discussed by direct shear test and SEM. The results obtained are as follows:

(1) The growth curve of bacterial number basically conforms with the Gompertz-Richards model. The lag stage phase of curve is not very obvious which indicated that the Sporosarcina Pasteurii chosen for the experiment is excellent. Through shaking flask experiments in cement solution, it indicated that the $\mathrm{CaCO}_{3}$ production of Sporosarcina Pasteurii in the cement solution was positively correlated with its physiological activity and the concentration of calcium sources, and it showed an increase at the first and then tended to be stable.

(2) The following can be found from the microbial immobilization experiments: the higher the solution concentration of $\mathrm{CaCl}_{2}$, the lower the discharge rate of bacterial liquid from the sand column, but high concentration of $\mathrm{CaCl}_{2}$ solution will affect the uniform distribution and migration of bacteria in the uranium tailings. 
TABLE 2: Table of calcium ion utilization.

\begin{tabular}{|c|c|c|c|c|}
\hline Curing time & $4 \mathrm{~d}$ & $8 \mathrm{~d}$ & $12 \mathrm{~d}$ & $16 \mathrm{~d}$ \\
\hline Calcium ion utilization rate of MICP & $65.56 \%$ & $67.34 \%$ & $64.31 \%$ & $62.46 \%$ \\
\hline Calcium ion utilization rate of blank reference & $9.55 \%$ & $2.93 \%$ & $2.78 \%$ & $1.78 \%$ \\
\hline
\end{tabular}

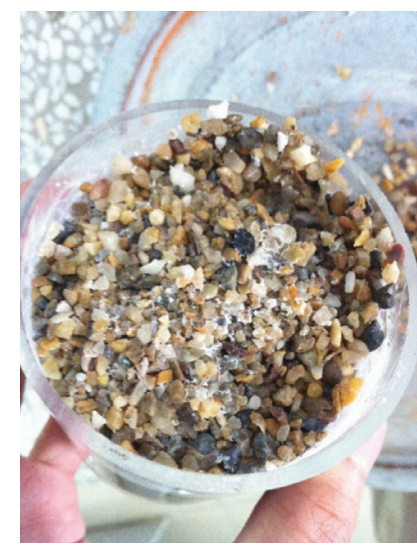

(a)

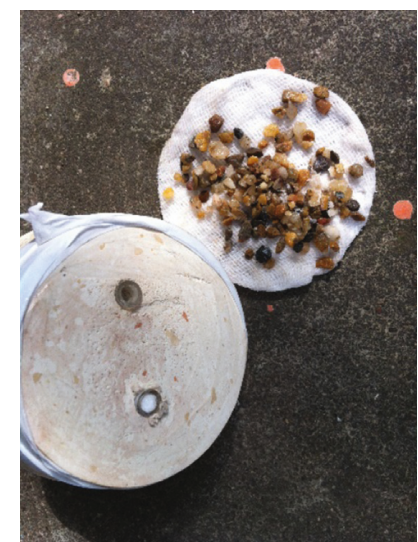

(b)

Figure 13: Deposition of $\mathrm{CaCO}_{3}$ in gravel layers and gauze layers: (a) buffer gravel layer; (b) grouting mouth and gauze layer.

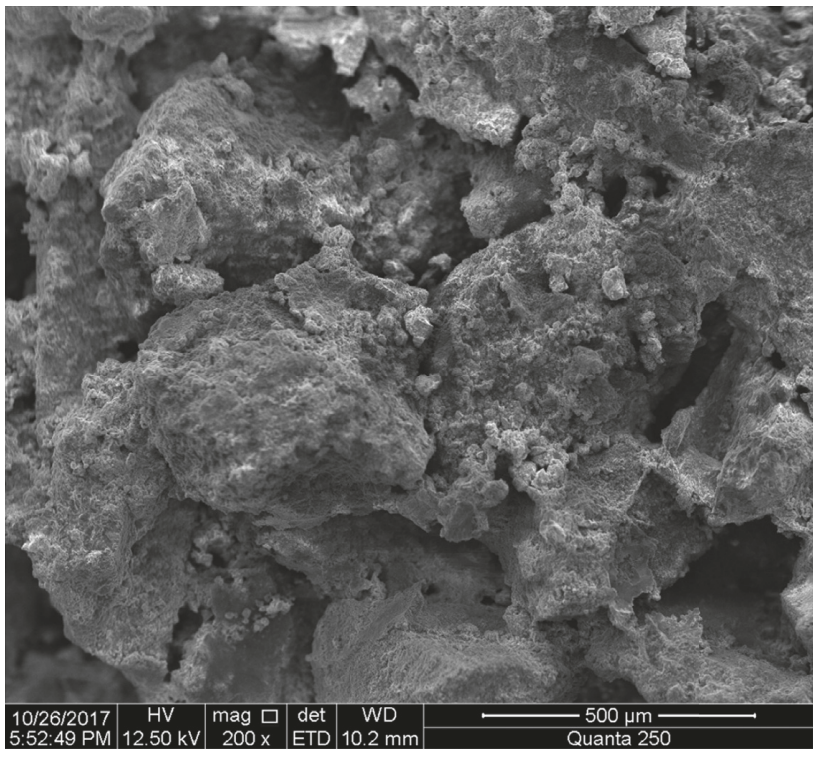

(a)

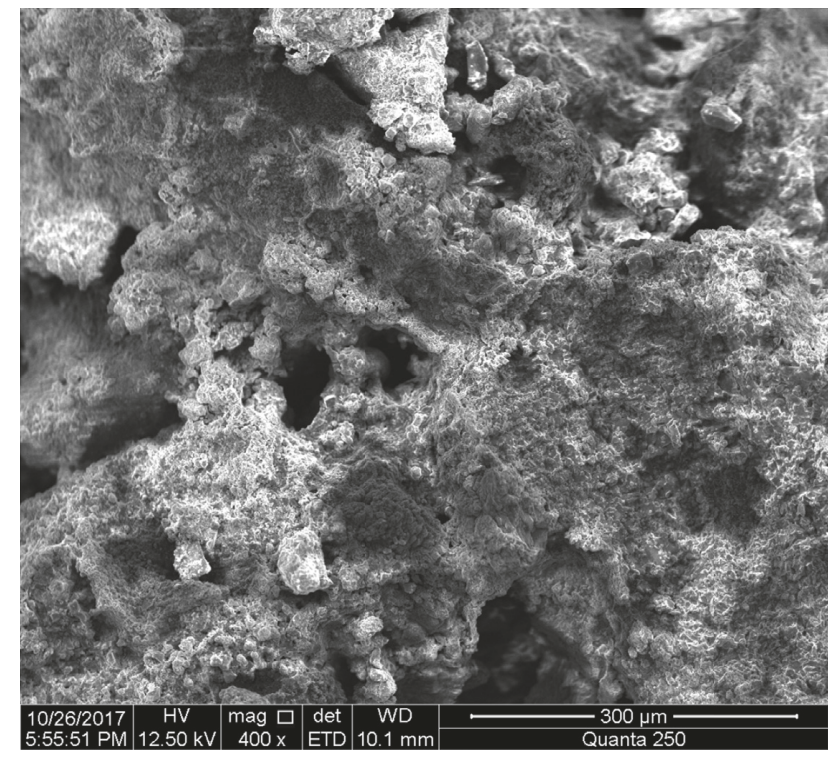

(b)

FIGURE 14: SEM images of uranium tailings reinforced by MICP at the end of experiment (200x:a; 400x: b).

(3) Sporosarcina Pasteurii was chosen for MICP experiment for $16 \mathrm{~d}$, and the shear strength of uranium tailings increased by $84.6 \%$ and $76.5 \%$, respectively, under $50 \mathrm{kPa}$ and $100 \mathrm{kPa}$ normal press. The results show that the MICP technology can increase the shear strength of fine-grained uranium tailings effectively. Through the scanning electron micrographs, the mechanism of uranium tailings reinforced by MICP was that calcite crystals produced by Sporosarcina
Pasteurii bind the uranium tailings particles together and form biological sandstones.

(4) The physical model and grouting mode should be further optimized to improve the production rate of $\mathrm{CaCO}_{3}$. And, the external factors (e.g., temperature and pressure) that influence the reinforced effect of uranium tailings by MICP should be considered, and the reinforcement depth should be further studied in the following experiments. 


\section{Data Availability}

The data that support the findings of this study are available from the corresponding author upon reasonable request.

\section{Conflicts of Interest}

The authors declare no conflicts of interest.

\section{Acknowledgments}

This study was supported by the National Natural Science Foundation of China (51774187), Science and Technology Department Key R\&D Plan Project of Hunan Province (2017SK2280), Nuclear and Radiation Safety Supervision Project of Ministry of Environmental Protection (1728-21), and Uranium Tailings Depot Resiliency Engineering Technology Research Center of Hunan Province.

\section{References}

[1] G. D. Mei, Research on Mechanism and Online Early-Warning Method for Tailings Dam Failure, University of Science and Technology Beijing, Beijing, China, 2015.

[2] H. D. Xu, "Statistical analyses of tailing reservoir disease accidents in China," Industrial Construction, vol. 31, no. 1, pp. 69-71, 2001.

[3] H. L. Liu and M. H. Zhao, "Review of ground improvement technical and its application in China," China Civil Engineering Journal, vol. 49, no. 1, pp. 96-115, 2016.

[4] C. X. Qian, A. H. Wang, and X. Wang, "Advances of soil improvement with bio-grouting," Rock and Soil Mechanics, vol. 36, no. 6, pp. 1537-1548, 2015.

[5] C. Q. Wang, K. F. Tan, P. X. Wang, and X. X. Xu, "Research status on grouting materials in China," Adhesion, vol. 11, pp. 87-91, 2013.

[6] V. S. Whiffin, Microbial $\mathrm{CaCO}_{3}$ Precipitation for the Production of Biocement, Murdoch University, Perth, Australia, 2004.

[7] L. A. V. Paassen, R. Ghose, T. J. M. van der Linden, W. R. L. van der Star, and M. C. M. van Loosdrecht, "Quantifying biomediated ground improvement by ureolysis: large-scale biogrout experiment," Journal of Geotechnical and Geoenvironmental Engineering, vol. 136, no. 12, pp. 1721$1728,2010$.

[8] L. A. V. Paassen, "Bio-mediated ground improvement: from laboratory experiment to pilot applications," in Proceedings of Geo-Frontiers Congress, pp. 4099-4108, Dallas, Texas, March 2011.

[9] M. B. Burbank, T. J. Weaver, T. L. Green, B. C. Williams, and R. L. Crawford, "Precipitation of calcite by indigenous microorganisms to strengthen liquefiable soils," Geomicrobiology Journal, vol. 28, no. 4, pp. 301-312, 2011.

[10] N. W. Soon, L. M. Lee, T. C. Khun, and H. S. Ling, "Factors affecting improvement in engineering properties of residual soil through microbial-induced calcite precipitation," Journal of Geotechnical and Geoenvironmental Engineering, vol. 140, no. 5, article 04014006, 2014.

[11] H. Canakci, W. Sidik, and I. H. Kilic, "Bacterail calcium carbonate precipitation in peat," Arabian Journal for Science and Engineering, vol. 40, no. 8, pp. 2251-2260, 2015.
[12] A. Mahawish, A. Bouazza, and W. P. Gates, "Biogrouting coarse materials using soil-lift treatment strategy," Canadian Geotechnical Journal, vol. 53, no. 12, pp. 2080-2085, 2016.

[13] D. S. S. Pusadkar, R. N. Tawalare, and D. A. I. Dhatrak, "Performance of footing on MICP induced slope," IOSR Journal of Mechanical and Civil Engineering, vol. 14, no. 3, pp. 100-105, 2017.

[14] A. M. Grabiec, J. Starzyk, K. Stefaniak, J. Wierzbicki, and D. Zawal, "On possibility of improvement of compacted silty soils using biodeposition method," Construction and Building Materials, vol. 138, pp. 134-140, 2017.

[15] J. T. DeJong, M. B. Fritzges, and K. Nusslein, "Microbially induced cementation to control sand response to undrained shear," Journal of Geotechnical and Geoenvironmental Engineering, vol. 132, no. 11, pp. 1381-1392, 2006.

[16] X. H. Cheng, Q. Ma, Z. Yang, Z. C. Zhang, and M. Li, "Dynamic response of liquefiable sand foundation improved by bio-grouting," Chinese Journal of Geotechnical Engineering, vol. 35, no. 8, pp. 1486-1495, 2013.

[17] N. K. Dhami, M. S. Reddy, and A. Mukherjee, "Biomineralization of calcium carbonates and their engineered applications: a review," Frontiers in Microbiology, vol. 4, no. 314, 2013.

[18] M. P. Harkes, L. A. van Paassen, J. L. Booster, V. S. Whiffin, and M. C. M. van Loosdrecht, "Fixation and distribution of bacterial activity in sand to induce carbonate precipitation for ground reinforcement," Ecological Engineering, vol. 36, no. 2, pp. 112-117, 2010.

[19] W. S. Ng, M. L. Lee, and S. L. Hii, "An overview of the factors affecting microbial-induced calcite precipitation and its potential application in soil improvement," World Academy of Science, vol. 6, no. 2, pp. 723-729, 2012.

[20] H. Rong, Preparation and Binding Mechanism of Microbe Cement, Southeast University, Nanjing, China, 2014.

[21] S. K. Ramachandran, "Remediation of concrete using microorganisms," ACI Material Journal, vol. 98, no. 1, pp. 3-9, 2001. 


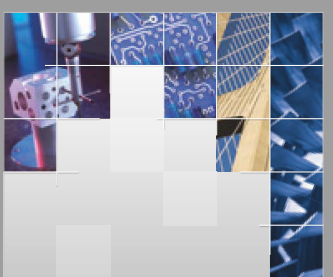

\section{Enfincering}
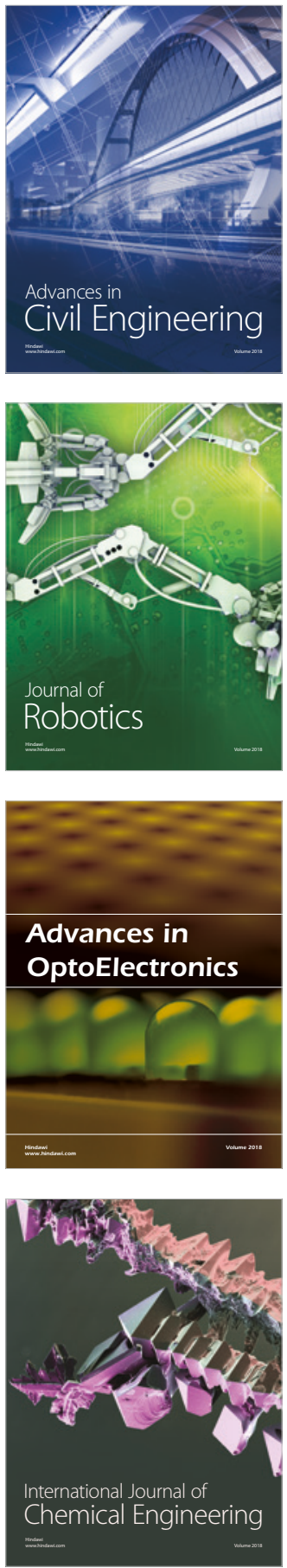

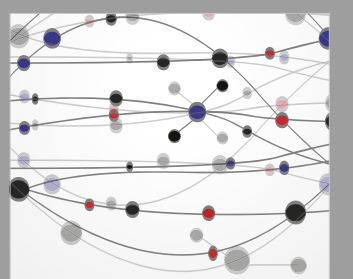

\section{Rotating \\ Machinery}

The Scientific World Journal

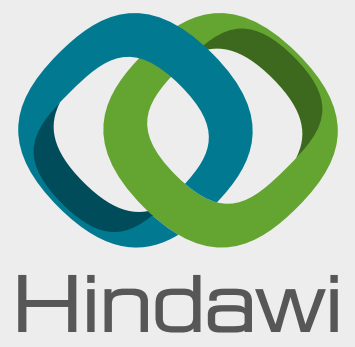

Submit your manuscripts at

www.hindawi.com
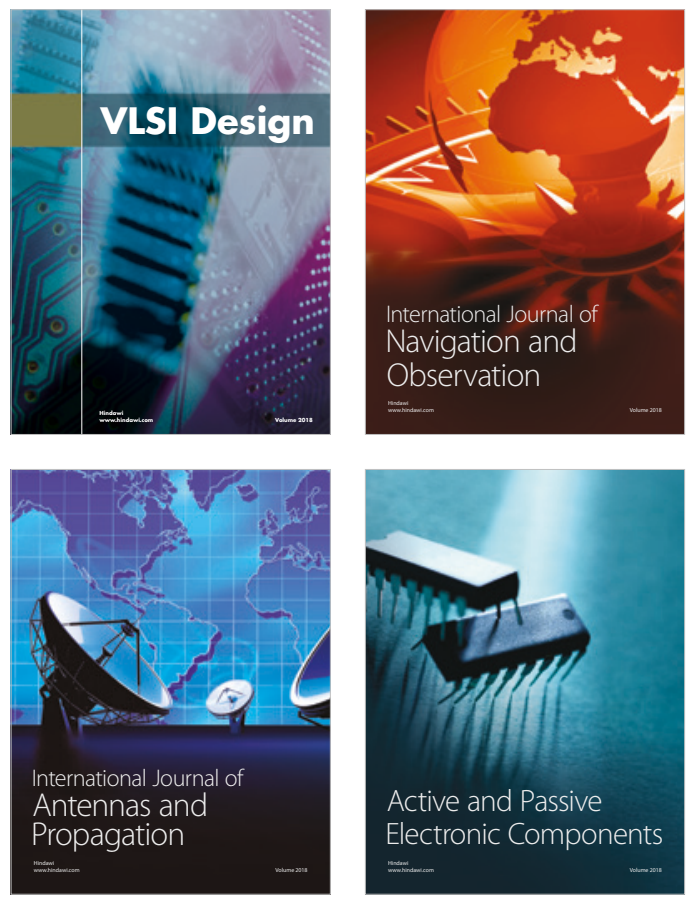
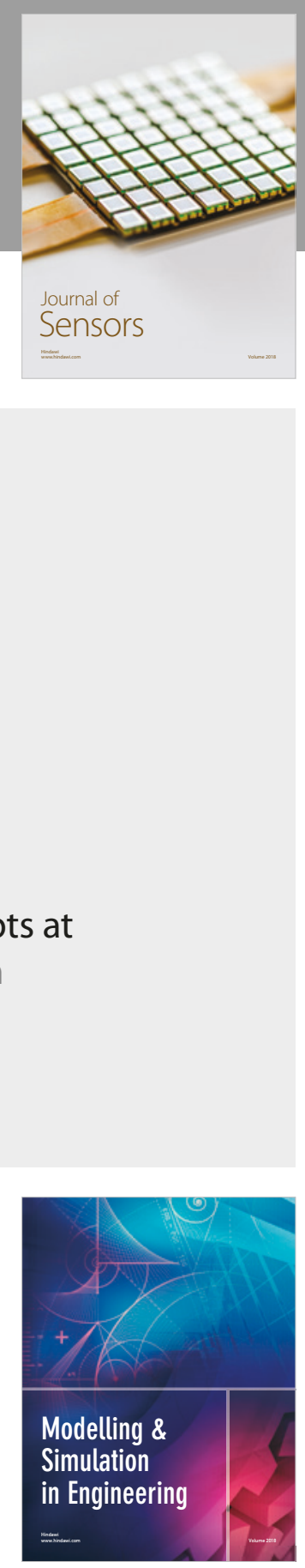

\section{Advances \\ Multimedia}
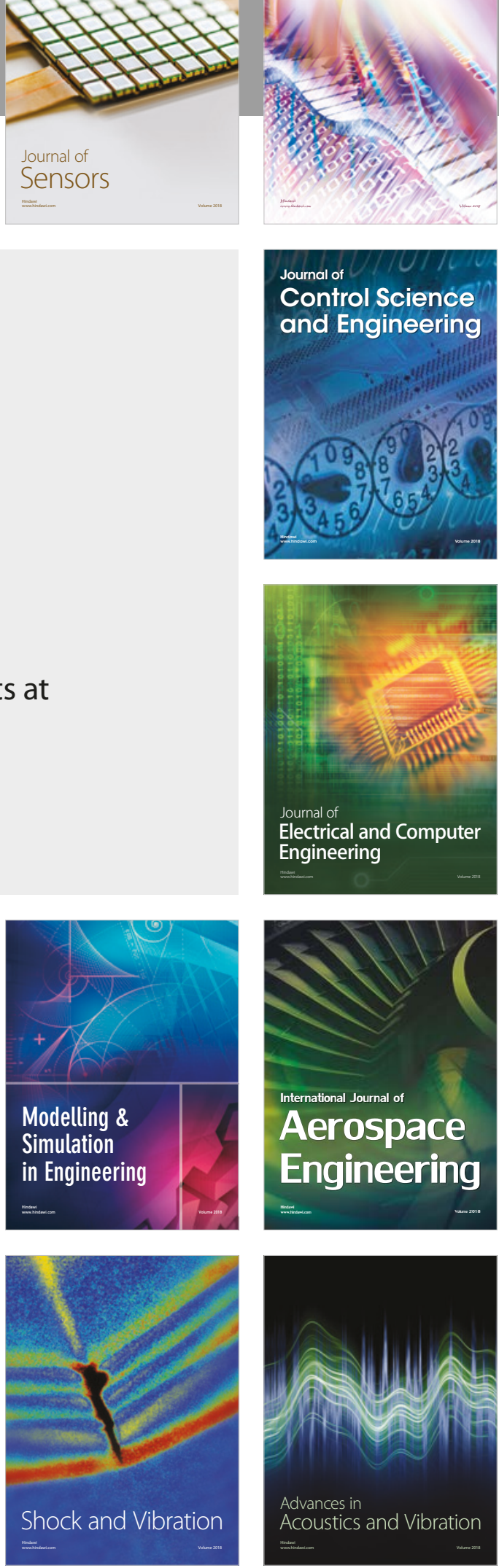